\title{
STRUCTURAL ANALYSIS AND MAPPING OF HISTORICAL TOMBS IN AHLAT DISTRICT (BITLIS, TURKEY)
}

Scientific paper / Znanstveni rad

\section{Ercan Işık}

(Received: 05 February 2019; accepted: 27 May 2019)

Bitlis Eren University, Associate professor

Corresponding author: eisik@beu.edu.tr

\section{Barış Antep}

Civil Engineer

\section{Aydın Büyüksaraç}

Bitlis Eren University, Full professor

\begin{abstract}
Tombs are an important part of the architecture in the ancient civilizations. Ahlat is a district located in the Lake Van Basin and has hosted many civilizations with its rich historical texture, a large part of which consists of tombs. In this study, observational structural analyses were performed for fifteen different tombs in the Ahlat district. Because of the investigations carried out in the field, the geometrical locations of the ditches were determined and mapping was carried out for these tombs. Damages in the tombs caused by natural reasons were determined and information about the preservation measures to be taken was provided. Finite element models were created for two selected tombs with different architectural characteristics that may represent the other tombs. The study aimed at determining the seismic behavior of the tombs for which two selected tombs were analyzed. Monumental buildings for historical heritage should be preserved for the next generations, which is possible if they could be investigated for structural characterizations. This study sets an example in that direction. The traceability of such structures is crucial for interventions in the historical buildings, which will become more practical with the help of the observational forms.
\end{abstract}

Keywords: tomb; structural analysis; historical; mapping; traceability

\section{PRORAČUN KONSTRUKCIJA I KARTIRANJE POVIJESNIH GROBNICA U AHLAT PODRUČJU (BITLIS, TURSKA)}

Sažetak: Grobnice su važan dio arhitekture drevnih civilizacija. Ahlat je područje smješteno u blizini jezera Van Basin i bio je dom mnogih civilizacija sa svojim bogatim povijesnim građevinama, čiji se veliki dio sastoji od grobnica. U ovom istraživanju proveden je konstrukcijski proračun za petnaest postojećih različith grobnica u okrugu Ahlat. Zbog istraživanja provedenih na terenu, točno su definirane lokacije grobnica te je provedeno njihovo kartiranje. Oštećenja na grobnicama koja su nastala tijekom vremena su definirana te su opisane mjere zaštite nužne za njihovo očuvanje. Proračun pomoću metode konačnih elemenata napravljen je za dvije odabrane grobnice s različitim arhitektonskim karakteristikama koje mogu predstavljati i druge grobnice. Cilj istraživanja bio je utvrditi moguće seizmičko ponašanje grobnica za koje su analizirane dvije odabrane grobnice. Monumentalne građevine za povijesnu baštinu treba sačuvati za sljedeće generacije, što je moguće ako se provedu istraživanja na razini proračuna karakteristika konstrukcije, što je i prikazano u radu. Praćenje stanja takvih objekata ključno je za potencijalne intervencije u povijesnim zgradama, koje može postati praktičnije pomoću obrazaca.

Ključne riječi: grobnica; proračun konstrukcije; povijesna baština; kartiranje; praćenje stanja

Işık, E, Antep, B, Büyüksaraç, A. 


\section{INTRODUCTION}

Since the beginning of humanity, the values created because of utilizing nature are called the cultural and natural heritage. Conserving these values is a problem in our times and should be emphasized [1,2].

One of the important aspects of cultural heritage is the historical buildings. Understanding their construction technologies and the construction materials has an important role in the interventions planned for such buildings. Traceability of historical structures is an important issue if these heritages are to be passed on to the future generations. As every civilization has its own unique style and construction technology, considering the different construction styles of the historical buildings, it is possible to gain knowledge about the past civilizations of that region.

Studies on historical buildings, which are an important part of the cultural heritage, have a particular significance today and thus require cooperation from different disciplines. This reveals the importance of interdisciplinary research [3-6]. Lake Van Basin is a settlement dating back to ancient times and has hosted many civilizations in the historical process. Many historical structures belonging to these civilizations have survived. The robustness of these structures, having been exposed to large earthquakes in the Lake Van Basin, which has a high risk of seismicity, is an indicator of their strength; thus, they require careful monitoring from the relevant institutions.

The survival of these historical buildings for centuries is directly related to the material properties and the construction technologies used in these structures. In this context, a structural analysis of such structures is an important engineering activity. There have been many studies on the structural analysis of historical structures in different parts of the world [7-18]. Many of these studies presented the reasons and results of the damages that occurred within selected historical buildings and proposed solutions for these problems. In some studies, the behaviors of the structures under the effect of earthquakes were investigated by using the finite elements method. These studies aim to provide information about the construction technologies of these structures. It may be stated that buildings belonging to different civilizations had different construction styles. However, more importantly, the constructability of such sound structures at a time when technology was not much developed indicates the utilization of unstructured engineering services in the building processes.

In this context, there are many buildings constructed in different styles by different civilizations in the Ahlat district in the Lake Van Basin. Some of these works are on the noble list of UNESCO. Ahlat is a city on the Silk Road; thus, it has a strategic location, and many civilizations have used it as a base. Its tombs are the most important assets of its historical heritage. In this study, fifteen large tombs, which are still surviving, in the Ahlat district were examined. Their geometric positions were determined by the measurements made on the land for each tomb. The mapping of the large tombs was conducted with the help of the determined coordinates. Alternative routes were set for domestic and foreign tourists to save time. The structural characteristics of the large tombs were determined by the structural analysis based on the observations made for each tomb. The causes and consequences of the damages that generally occurred in the large tombs were examined. One of the objectives of the study was to obtain information about the construction technologies that were used for the large tombs in the district. The fact that these large tombs survived increases the importance of their construction technologies. In this study, a detailed structural analysis for the Sheikh Necmeddin and Erzen Hatun tombs was carried out by creating a finite element model. The behaviors of the large tombs under the influence of earthquakes were determined.

The tombs found in the studied area are a significant part of the mausoleum culture that is based on the phenomenon of burying the dead and praising individuals at ruling positions for the future; this culture can be traced far back among Eastern societies. These tombs, built as mausoleums and as places of worship, constitute a historical heritage worth preserving for the future. This makes the conditions of the buildings that survived the negative effects of time and the external variables particularly important to reveal the destructive effects they have experienced and the conditions crucial to their preservation. With this study, observation-based damage information for the historical structures was obtained for the first time. Monitoring this information through time should contribute meaning to the future interventions. Researchers can discuss if the locations of these tombs have a meaningful pattern, with the help of the accurate locations given in this study.

Işık, E, Antep, B, Büyüksaraç, A. 


\section{MATERIALS AND METHODS}

Tombs are the most original examples of the architecture of different civilizations. It is possible to encounter large tombs in different parts of the world constructed using different materials in different ways in accordance with the architectural understanding of their period. They were built in the style of masonry using local materials. However, the shape, number of stories, forms, and appearances of these large tombs may vary. They are generally built on a rectangular pedestal. After the floors above the base, they are covered with a roof called a cone. Examples include mausoleums belonging to the ancient periods. This type of artwork was built in different ways worldwide. Graves are just as magnificent as monumental tombs. They are an important part of the historical buildings that reveal all the architectural characteristics and remnants of their time. Therefore, every study about such structures is important and helps to protect their cultural and historical heritage.

Several studies have been published in the literature on historical monumental structures [18-23]. However, most of these studies are not comprehensive, and they generally focus on a single tomb. In this study, the structural properties of tombs and their behavior under the effects of earthquakes were investigated. Fifteen tombs in the Ahlat district were studied. Each analyzed tomb has an ID number. Pictures of large tombs are shown in Figure 1.

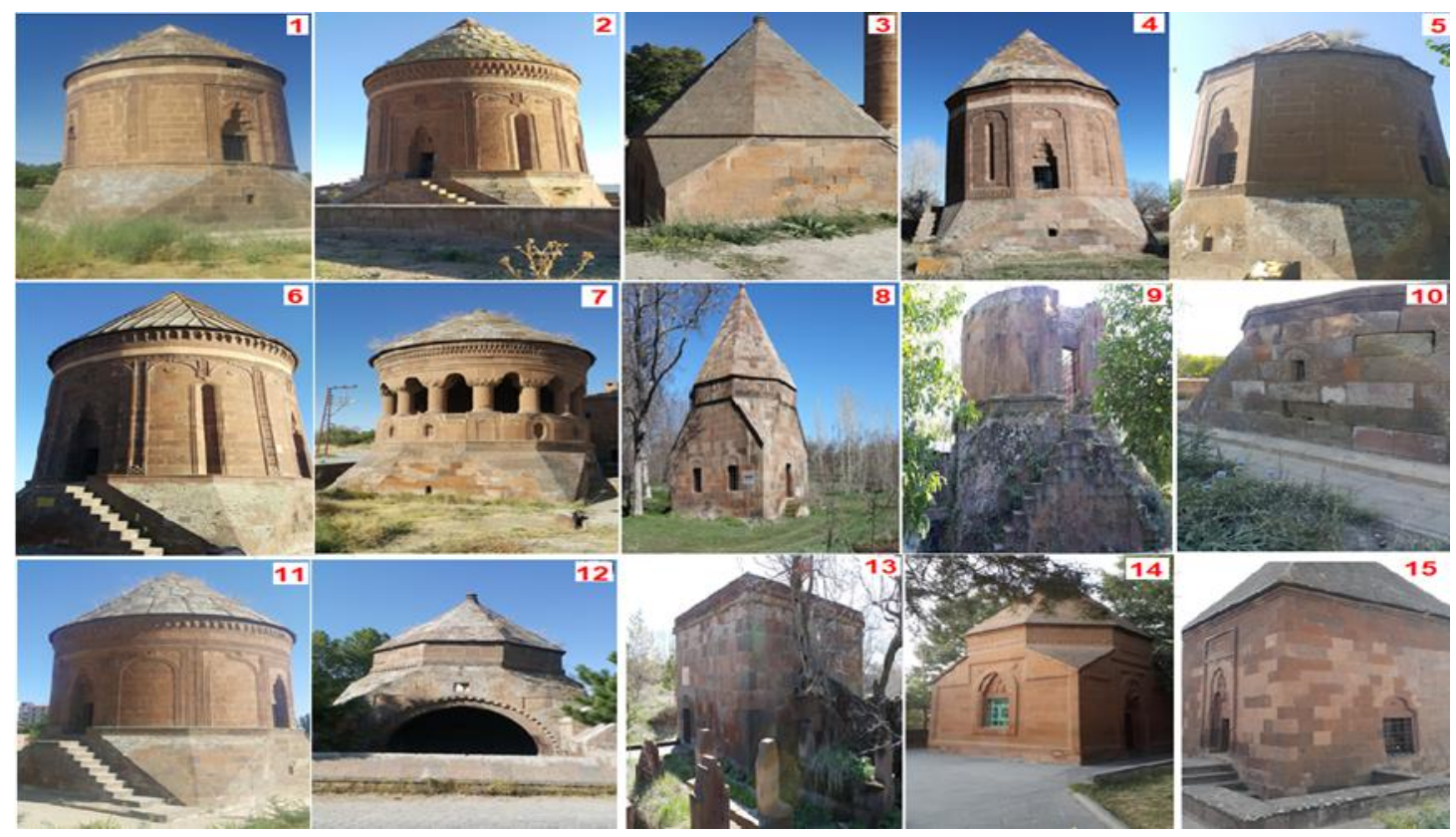

Figure 1 Large tombs in the Ahlat district

\subsection{Mapping and Structural Properties of the Tombs}

Maps can be thematic or topographical with different scales for general information, culture, and usage. Mapping is one of the most important aspects of civil engineering applications. It requires a sufficient and necessary number of parameters to be expressed in numerical terms [24, 25]. According to the determined ID numbers, the geometrical positions in Point Sense were made separately for each group. During the mapping process, the tombs in the Ahlat district, which were the subjects of this study, were considered. For mapping, it is necessary to determine the boundaries and obtain the geometrical details. The obtained historical building location data were transferred to the computer. Determination of the geometrical positions of the structures and their mapping allows their healthy monitoring. Additionally, it will allow local and foreign tourists to visit through alternate routes without any guidance. Route selection may be planned more easily. The map of the subject, the Ahlat tombs, is the first comprehensive tombs map prepared for the district (Figure 2). The fact that some tombs are very close to each other owing to their geometrical position caused them to overlap on the map. At the town entrance of Ahlat, densities appear concentrated. Thirteen of the fifteen tombs are very close to each other. Table 1 shows some characteristics of the tombs examined in the study.

Işık, E, Antep, B, Büyüksaraç, A. 


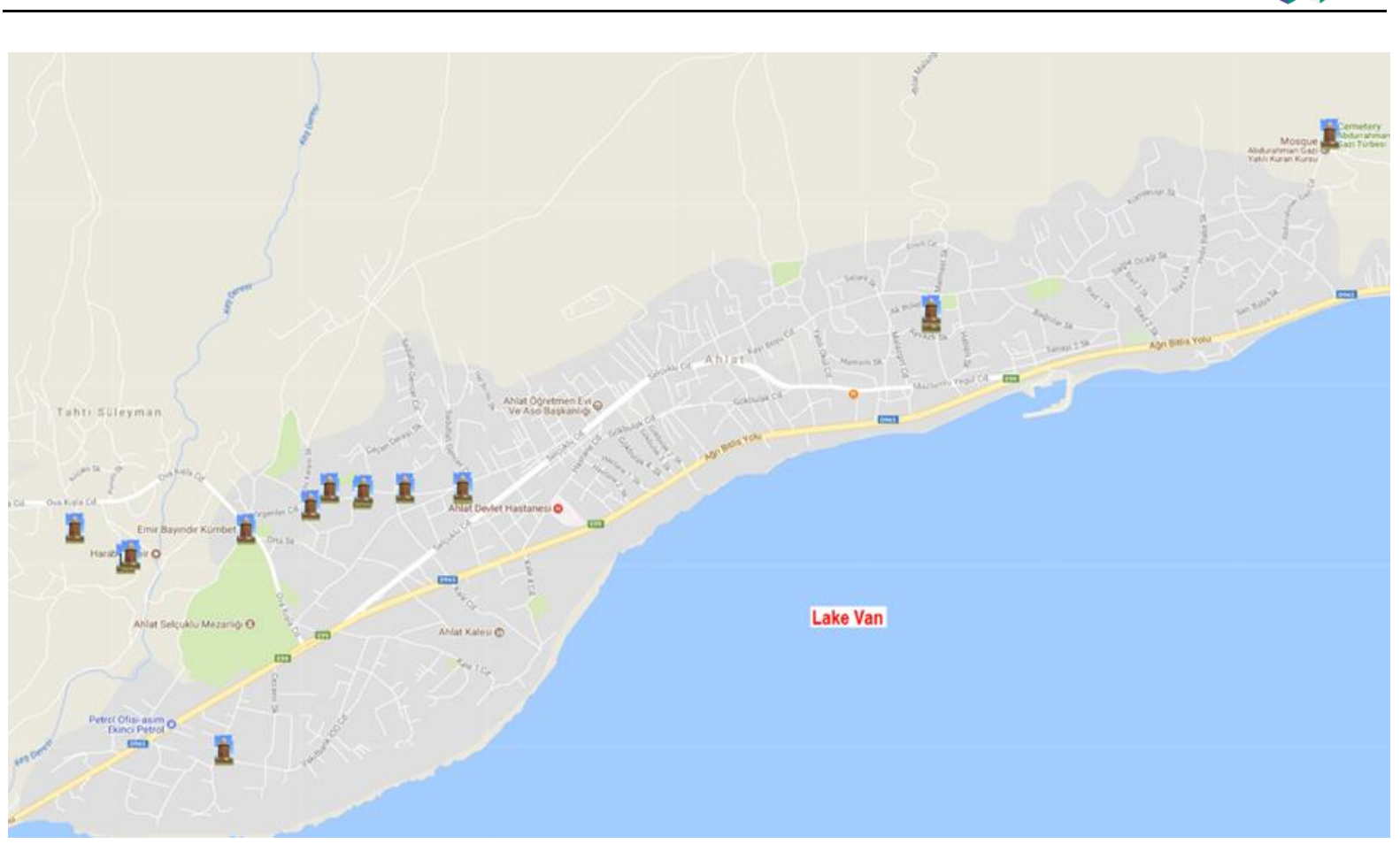

Figure 2 Presentation of the tombs in the Ahlat district

Table 1 Characteristics of the tombs

\begin{tabular}{|c|c|c|c|c|c|}
\hline ID & Name of the monument & Size (m) & $\begin{array}{l}\text { Shape of the } \\
\text { Structure }\end{array}$ & $\begin{array}{l}\text { Number of } \\
\text { floors }\end{array}$ & Shape of the roof cover \\
\hline 1 & Hüseyin Timur Tomb(Çifte) & $6.72 \times 6.72$ & Cylinder & 2 & Conical cone \\
\hline 2 & Usta Şagird (Ulu) Tomb & $9.00 \times 9.00$ & Cylinder & 2 & Conical cone \\
\hline 3 & Mirza Bey Tomb & $6.20 \times 6.20$ & Octagon & 1 & Pyramidal cone \\
\hline 4 & Erzen Hatun Tomb & $6.60 \times 6.60$ & Dodecagon & 2 & Pyramidal cone \\
\hline 5 & Keşiş Tomb & $6.20 \times 6.20$ & Dodecagon & 2 & Pyramid \\
\hline 6 & Hasan Padişah Tomb & $9.95 \times 9.95$ & Cylinder & 2 & Conical cone \\
\hline 7 & Emir Bayındır Tomb & $6.37 \times 6.47$ & Cylinder & 2 & Conical cone \\
\hline 8 & Anonim Tomb (2) & $6.95 \times 6.95$ & Octagon & 1 & Pyramid \\
\hline 9 & Alimoğlu Hurşit Tomb & $8.33 \times 8.33$ & Cylinder & 2 & Null \\
\hline 10 & Anonim Tomb (I) & $5.90 \times 5.90$ & Octagon & 2 & Null \\
\hline 11 & $\begin{array}{c}\text { Buğatay Aka-Şirin Hatun } \\
\text { Tomb }\end{array}$ & $7.84 \times 7.84$ & Cylinder & 2 & Conical cone \\
\hline 12 & Emir Ali Tomb & $9.10 \times 6.05$ & Pyramid & 1 & Pyramid \\
\hline 13 & DedeMaksut Tomb & $6.46 \times 5.73$ & Rectangle & 1 & Flat \\
\hline 14 & Abdurrahman Gazi Tomb & $5.30 \times 5.30$ & Octagon & 1 & Pyramid \\
\hline 15 & Şeyh Necmeddin Tomb & $5.10 \times 5.10$ & Square & 2 & Pyramid \\
\hline
\end{tabular}

To provide an example of the sections and plans of the tombs in the Ahlat district, the drawings of two tombs are shown in Figure 3.

Işık, E, Antep, B, Büyüksaraç, A. 

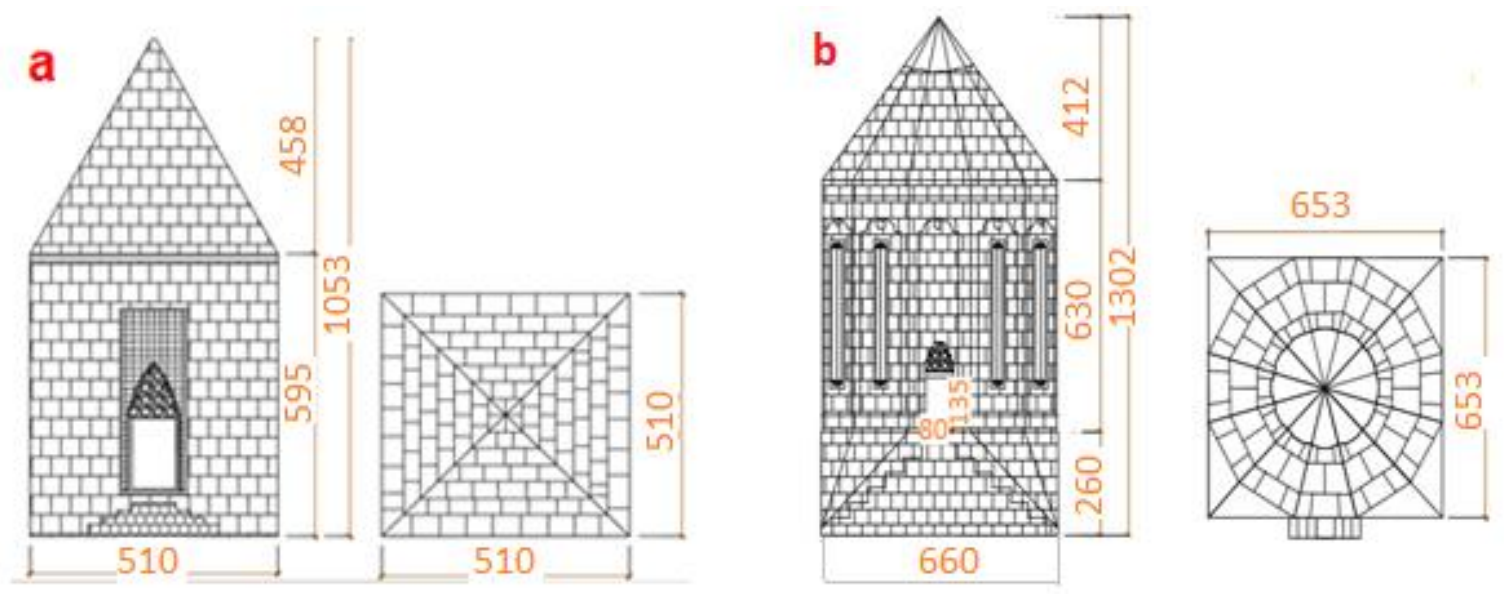

Figure 3 Plans and sections of two different tombs (a) Sheikh Necmeddin and (b) ErzenHatun

\subsection{Damages Observed in the Tombs}

The stones obtained from the stone quarries in the Ahlat district, called the Ahlat stone, were used in the buildings after cutting processes for different purposes. One of the general characteristics of the Ahlat stone is discoloration and color change due to effects of the natural conditions with time. Discoloration and color change were observed in almost all of the examined structures. The area where the buildings are located experiences heavy snow and rain. Excessive rainfall has led to calcification in some of the investigated structures. Additionally, the use of excess water in garden irrigations in the settlements close to the structures has negatively impacted these structures. Some of the stones used in the structure have abrasions and ruptures. Abrasions were observed in some of the joints used for joining the stones. Sealing of joints was not observed. The joints were constructed with the method of diversion to increase the engagement of the stones forming the wall under loads. As the ground properties were good in the examined buildings, it was observed that there were almost no settling effects with time. A basement floor model was designed for each structure. A section similar to the basement floor was built in most of the tombs. All the tombs had been affected by several natural disasters. Lake Van Basin, where the district is located, has a risky potential in terms of seismicity. In the basin, there have been devastating earthquakes with $M>6$ in Ahlat (1881), Malazgirt (1903), Erçiş (1941), Çaldıran (1976), and Van (2011). These earthquakes had affected all the examined structures. Although they were exposed to these devastating earthquakes, they were not greatly damaged. This shows how advanced the construction technologies of these structures were. The existence of vegetative formations appears clearly in the main part of the investigated buildings, in addition to different parts of the structure, however it did not create a very big damage. Repairs and renovations had been conducted in the past in all the structures that were examined, which is an important step in maintaining the authenticity of the structures and extending their life. The maintenance and restoration of these structures is not random. These processes are designed and decided by relevant institutions to be held at appropriate times. One of the damages caused by the people included writing their names around the tombs irresponsibly. Additionally, the use of drilling materials like nails to install doors and windows caused different damages. All tombs were built in the masonry building style. The structures were built on a square or a rectangular base usually consisting one compartment and were symmetrically constructed. No damage in the structural system elements constituting the structure was found. No deformation was observed in the horizontal or the vertical direction. In addition to the dome-shaped shelters, only a very small portion had flat roofs. For example, in the Dede Maksut Tomb, to make the roof of the building invisible from outside, a device consisting the local stones called a raft was placed around the roof covering. Additionally, in the section described as the roof, water troughs called çoratan in Turkish were placed around the floor. The purpose of using çoratans is to provide drainage for the precipitation water from the roof. One of the reasons for destruction is treasure hunting and theft of building stones. The stones used in these structures are generally used in garden masonry works and transportation of the smuggled historical artifacts. The observations form for the damages occurred in all the tombs considered, are shown in Table 2. The ID numbers given in the previous section were used. The images of different types of damages and destructions in the tombs are shown in Figure 4.

Işık, E, Antep, B, Büyüksaraç, A. 
Table 2 Damage based on the observations of the studied tombs

\begin{tabular}{|c|c|c|c|c|c|c|c|c|c|c|c|c|c|c|c|}
\hline Parameter/Tomb ID & 1 & 2 & 3 & 4 & 5 & 6 & 7 & 8 & 9 & 10 & 11 & 12 & 13 & 14 & 15 \\
\hline Distortion with time effect & $x$ & $x$ & $x$ & $x$ & $x$ & $x$ & $x$ & $x$ & $x$ & $x$ & $\mathrm{X}$ & $x$ & $x$ & $x$ & $x$ \\
\hline Impact of natural conditions & $x$ & $x$ & $x$ & $x$ & $x$ & $x$ & $x$ & $x$ & $x$ & $x$ & $x$ & $X$ & $x$ & $x$ & $x$ \\
\hline Destruction by people & $x$ & $x$ & $x$ & $x$ & $x$ & $x$ & $x$ & $x$ & $x$ & $x$ & & $x$ & $x$ & & $x$ \\
\hline $\begin{array}{c}\text { Active use of structure } \\
\text { Neglect }\end{array}$ & $x$ & $x$ & $x$ & $x$ & $x$ & $x$ & $X$ & $\begin{array}{l}X \\
X\end{array}$ & $x$ & $x$ & $x$ & $X$ & $x$ & $x$ & $x$ \\
\hline Is it originally preserved? & $x$ & $x$ & $x$ & $x$ & $x$ & $x$ & $X$ & $X$ & $x$ & $x$ & $\mathrm{X}$ & $X$ & $x$ & $x$ & $x$ \\
\hline Dislocation of the building stones & & & & & & & & & & $x$ & & & & & \\
\hline Breaking and splitting & & $x$ & $x$ & & $x$ & & $X$ & $X$ & $x$ & $X$ & $x$ & $X$ & $x$ & & $x$ \\
\hline Calcification of surfaces & & $x$ & $x$ & $x$ & $x$ & $x$ & $\mathrm{X}$ & $x$ & $x$ & $x$ & $\mathrm{X}$ & $x$ & $x$ & & $x$ \\
\hline Wear of wall joints & & & & & $x$ & & $X$ & & $x$ & & $\mathrm{X}$ & & $x$ & & $x$ \\
\hline Seaweeds and vegetative formations & $x$ & $x$ & $x$ & $x$ & $x$ & $x$ & $\mathrm{X}$ & $x$ & $x$ & $x$ & $\mathrm{X}$ & $x$ & $x$ & $x$ & $x$ \\
\hline Repair or not & $x$ & $x$ & $x$ & $x$ & $x$ & $x$ & $X$ & & $x$ & $X$ & $\mathrm{X}$ & $X$ & $X$ & $X$ & $\mathrm{x}$ \\
\hline The presence of germinated soil layer & & & & & & & & & & $x$ & & & & & \\
\hline Cracks & $x$ & $x$ & $x$ & $x$ & $x$ & & $\mathrm{X}$ & $x$ & $x$ & $X$ & $x$ & $X$ & $X$ & & $x$ \\
\hline Blackening and decay on surfaces & $x$ & $x$ & $x$ & $x$ & $x$ & $x$ & $\mathrm{X}$ & $\mathrm{X}$ & $\mathrm{X}$ & $x$ & $\mathrm{X}$ & $x$ & $x$ & $x$ & $x$ \\
\hline Mass loss & & & & & & & & $X$ & & & & & & & \\
\hline Sealing of joints & & & & & & & & & & & $\mathrm{X}$ & & & & \\
\hline Cracking due to rootstocks of plants & & & & & & & $\mathrm{X}$ & & & & & $X$ & & & \\
\hline Existence of water entering the structure & & & & & & $\mathrm{X}$ & & & & $\mathrm{X}$ & & & $x$ & & \\
\hline Freezing - thawing effect & $x$ & $x$ & $x$ & $x$ & $x$ & $x$ & $\mathrm{X}$ & $X$ & $x$ & $x$ & $x$ & $x$ & $X$ & & $x$ \\
\hline Effect of the surrounding building & $x$ & $x$ & $x$ & $x$ & $x$ & $x$ & $\mathrm{X}$ & $x$ & $x$ & $x$ & $x$ & $x$ & $X$ & & $x$ \\
\hline Color cast and color change & $X$ & $X$ & $X$ & $X$ & $X$ & $X$ & $X$ & $X$ & $X$ & $\mathrm{X}$ & $\mathrm{X}$ & $\mathrm{X}$ & $\mathrm{X}$ & $\mathrm{X}$ & $X$ \\
\hline
\end{tabular}

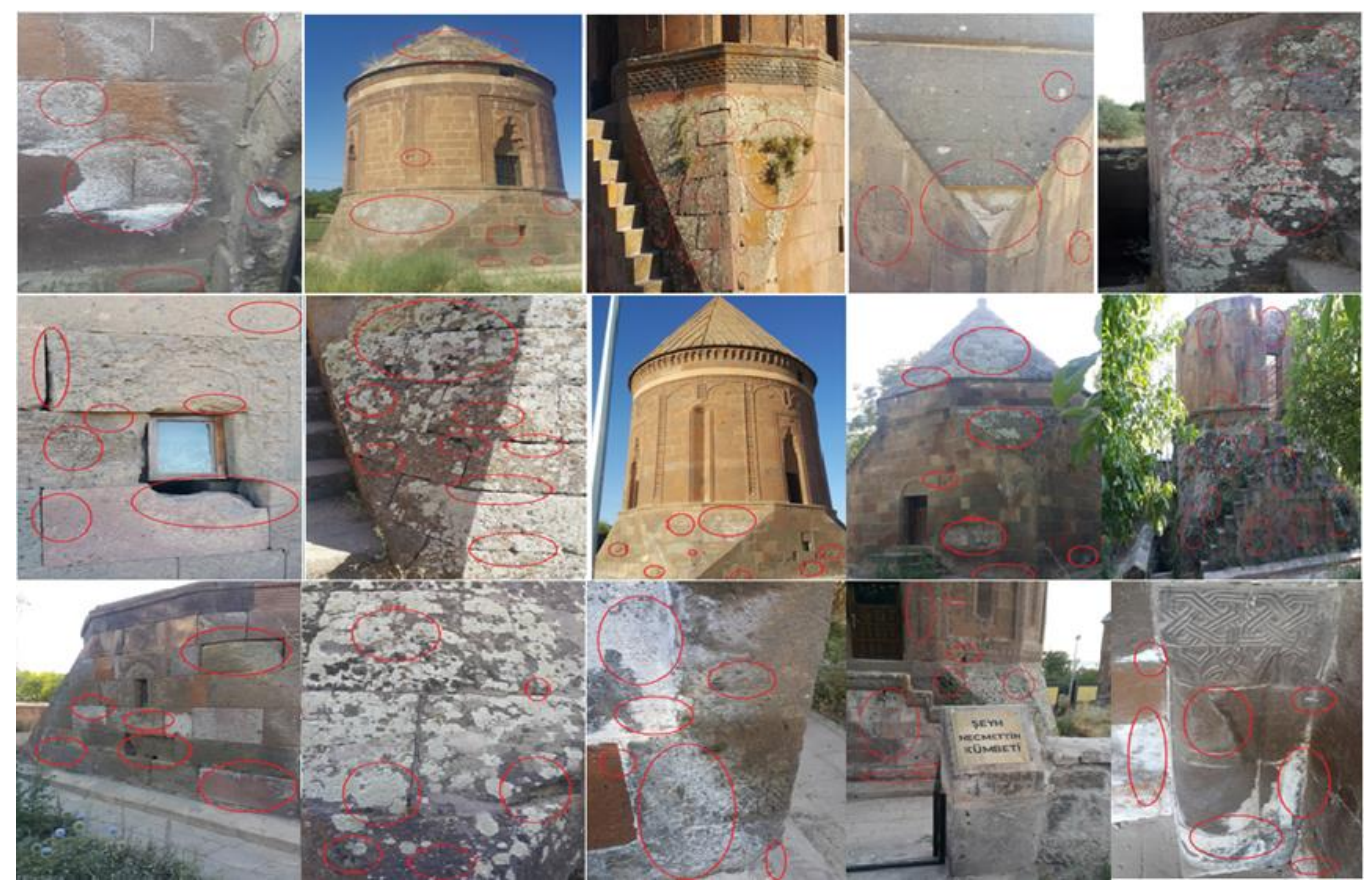

Figure 4 Different types of damages in different tombs

Işık, E, Antep, B, Büyüksaraç, A. 


\subsection{Analysis of the Selected Tombs with Finite Elements}

After observation-based structural analysis for all the tombs, detailed structural analyses were conducted for two tombs with different architectural styles that could represent the others. The tombs considered in this study belong to Sheikh Necmettin and Erzen Hatun. The Sheikh Necmettin Tomb was built on a $5.10 \times 5.10 \mathrm{~m}$ square plan with a total height of $10.53 \mathrm{~m}$. The Erzen Hatun Tomb was built on a $6.60 \times 6.60 \mathrm{~m}$ square plan with a height of 13.02 $\mathrm{m}$. The visuals of and the inscriptions on the tombs are shown in Figure 5.

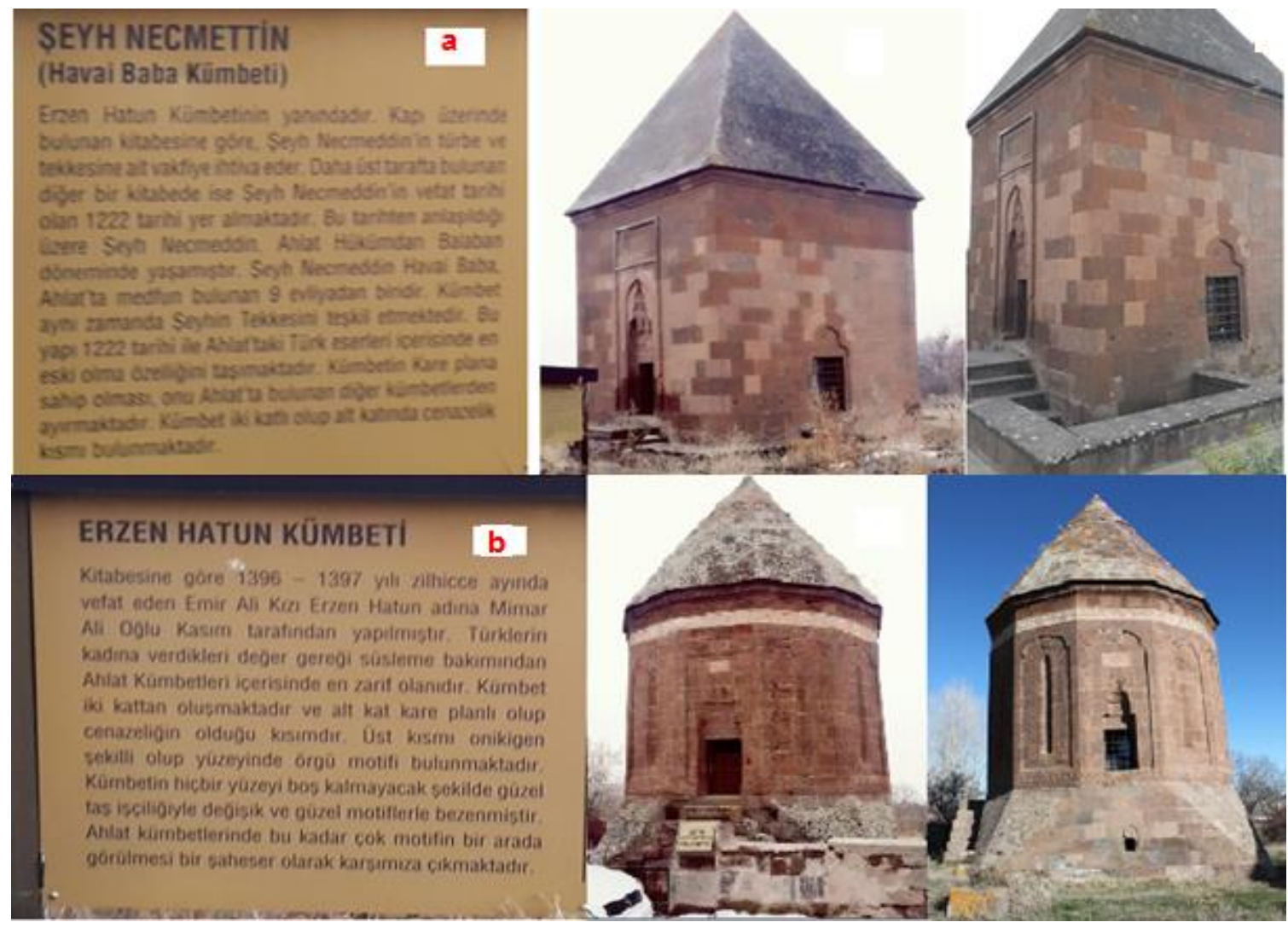

Figure 5 Images and inscription of the tombs of the study (a) Sheikh Necmeddin (b) Erzen Hatun

A seismic analysis of the studied tombs was carried out in the SAP2000 software [26]. The finite element models that were obtained with the software are shown in Figure 6.
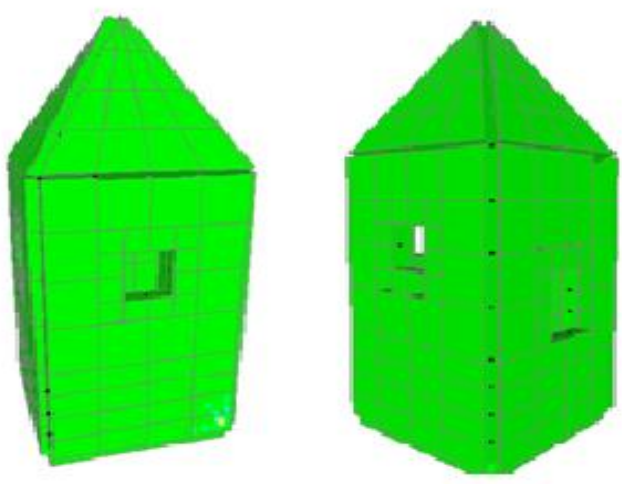

Sheikh Necmeddin

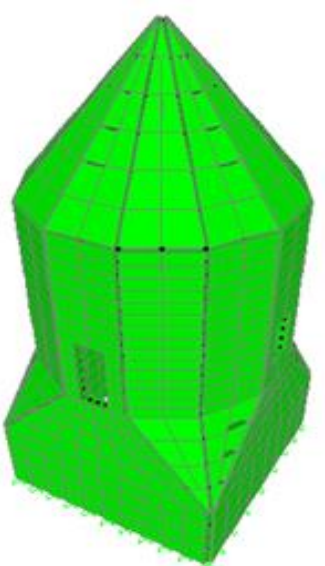

Erzen Hatun

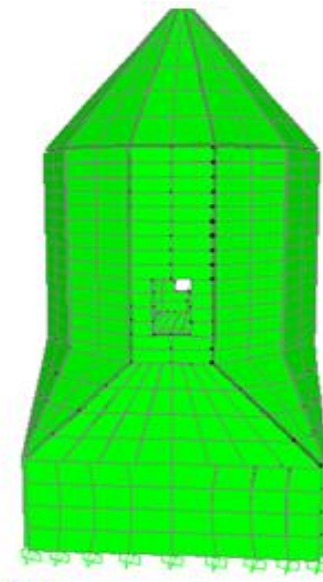

Figure 6 Finite element model of the tombs created with the software

Işık, E, Antep, B, Büyüksaraç, A. 
In all the structures examined, Ahlat stone was assumed the only material used. The material properties of the building components were taken from the results of the previous studies and the recommended values for the masonry structures in the Turkish Earthquake Code (TEC, 2007) [27]. The modulus of elasticity (E) and weight per unit volume $(\mathrm{y})$ for the Ahlat stone were taken as constant for all the structures. The characteristics of the material that was used are given in Table 3.

Table 3 Material properties

\begin{tabular}{ccccc}
\hline Type of material & $\begin{array}{c}\text { Modulus of elasticity } \\
\left(\mathbf{k N} / \mathbf{m}^{2}\right)\end{array}$ & $\begin{array}{c}\text { Specific weight } \\
\left(\mathbf{k N} / \mathbf{m}^{3}\right)\end{array}$ & $\begin{array}{c}\text { Weight per unit } \\
\text { volume }\left(\mathbf{t} / \mathbf{m}^{3}\right)\end{array}$ & Poisson's ratio \\
\hline Ahlat Stone & 5000000 & 24 & 2.45 & 0.2 \\
\hline
\end{tabular}

One of the modeling methods for masonry structures is macro modeling in which no distinction is made between the structural elements that constitute the masonry structure and the mortar mixture, and the structural elements are assumed composite. This way, an equivalent material model that reflects the common properties of the structural element and the mixture may be used [28]. Macro modeling was also used in this study to create the models of the tombs. The Ahlat stone used in the tombs and the mixture that connected the pieces of this stone were assumed a single material.

On the prepared calculation model, two different loading scenarios were applied, where the forcers created by fixed loads and earth movement defined by the earthquake spectrum were considered. The spectrum was applied separately in two principal directions, $E Q_{x}$ and $E Q_{y}$. The spectrum curve used in the dynamic analysis of the examined tombs is shown in Figure 7.

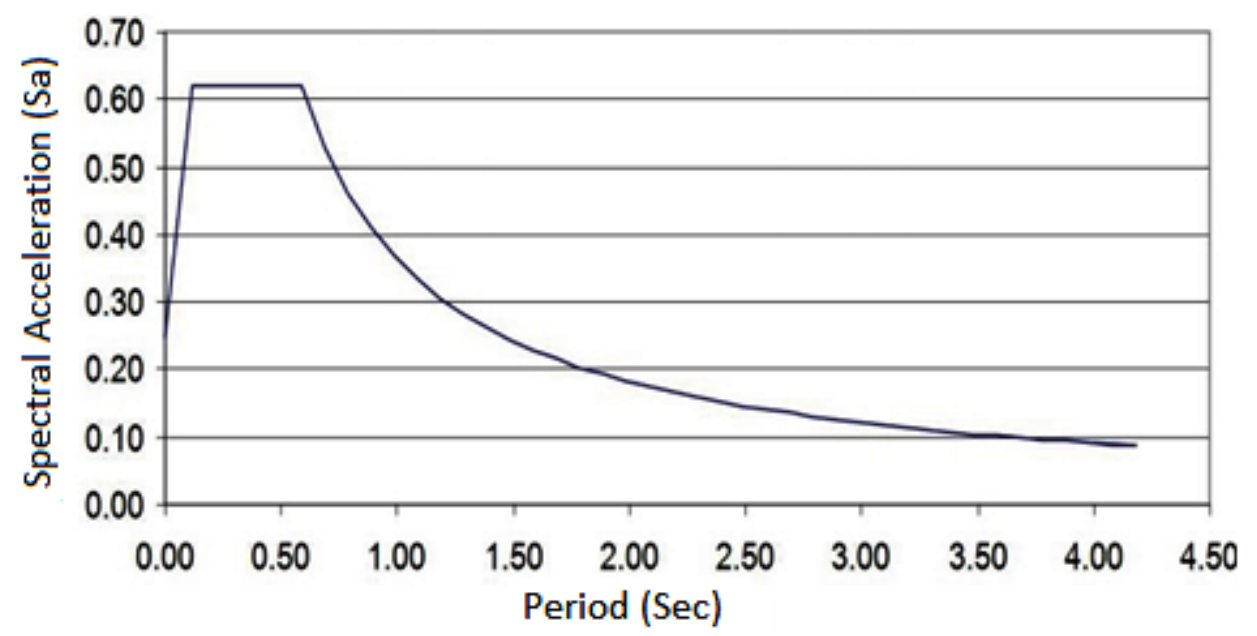

Figure 7 Spectrum curve for dynamic analysis

The sign conformities and direction assumptions of the elements used in the finite elements model of the structure are shown in Figure 8, in compliance to the assumptions projected by the software in which the numerical modeling was carried out.
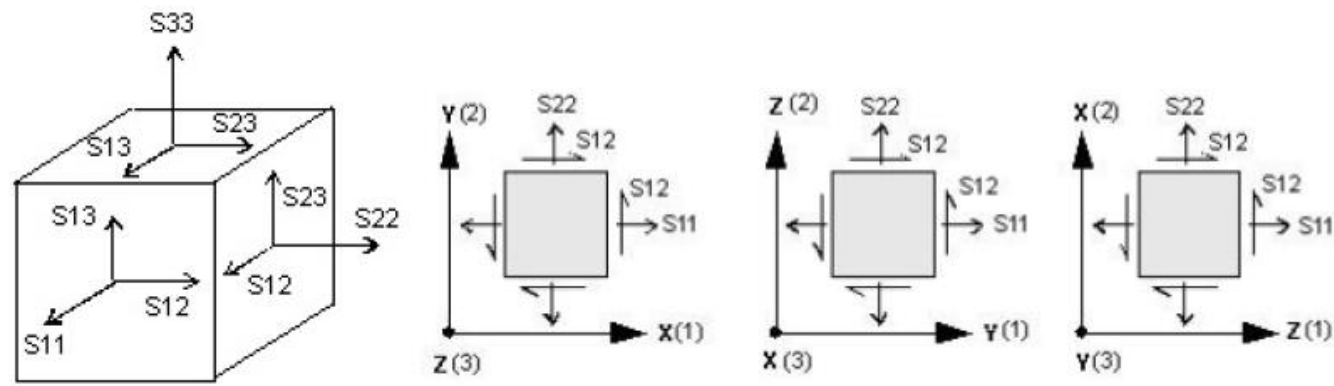

Figure 8 Sign conformance and direction assumptions [29]

Işık, E, Antep, B, Büyüksaraç, A. 
The prepared finite element models consisted of 261 nodes and 238 shell elements for the Sheikh Necmeddin Tomb, and 896 nodes and 815 shell elements for the Erzen Hatun Tomb. The dynamic properties of the tombs were determined by modal analysis. While the modal analysis was being performed, the first 18 modes were considered for these tombs. In the model, the modes higher than $80 \%$ of the mass participation rates in the $X$ and $Y$ directions were taken into consideration. Therefore, it was observed that taking more modes did not have much effect. According to the results of the model modal analysis of the effective modes of natural vibration periods, the mass participation rates are shown in Table 4, and the mode shapes are shown in Figure 9.

Table 4 Modal analysis results with effective mass participation rates of the models

\begin{tabular}{|c|c|c|c|c|c|c|c|c|c|c|c|c|c|c|}
\hline Mod & $\begin{array}{c}\text { Model } \\
\text { Type }\end{array}$ & Period & $\mathrm{U}_{\mathrm{x}}$ & $U_{Y}$ & $U_{z}$ & $\sum U_{x}$ & $\sum U_{Y}$ & $\Sigma U_{z}$ & $\mathbf{R}_{x}$ & $\mathbf{R}_{Y}$ & $\mathbf{R}_{\mathbf{z}}$ & $\sum R_{x}$ & $\sum \mathrm{R}_{\mathbf{Y}}$ & $\sum \mathbf{R}_{\mathbf{z}}$ \\
\hline \multirow{2}{*}{1} & a & 0.794159 & 0.70218 & 0 & 0 & 0.70218 & 0 & 0 & 0 & 0.86123 & 0.21843 & 0 & 0.86123 & 0.21843 \\
\hline & b & 0.163019 & 0.2357 & 0.42125 & 0.00312 & 0.2357 & 0.42125 & 0.00312 & 0.31034 & 0.22155 & 0.00033 & 0.31034 & 0.22155 & 0.00033 \\
\hline \multirow{2}{*}{2} & a & 0.793514 & 0 & 0.70228 & 0.00000179 & 0.70218 & 0.70228 & 0 & 0.81633 & 0 & 0.21861 & 0.86133 & 0.86124 & 0.43704 \\
\hline & b & 0.141386 & 0.38343 & 0.23728 & 0.0008 & 0.61913 & 0.65852 & 0.00392 & 0.14946 & 0.34586 & 0.00262 & 0.4598 & 0.56741 & 0.00295 \\
\hline \multirow{2}{*}{3} & a & 0.189557 & $3,16 \mathrm{E}-16$ & 0.00001 & 0.99524 & 0.70218 & 0.70229 & 0.99524 & 0.12394 & 0.12402 & 0 & 0.98527 & 0.98525 & 0.43704 \\
\hline & b & 0.106623 & 0.00642 & 0.0337 & 0.00063 & 0.62555 & 0.69223 & 0.00455 & 0.05166 & 0.02109 & 0.0271 & 0.51147 & 0.5885 & 0.03005 \\
\hline \multirow{2}{*}{4} & a & 0.056906 & 0.00083 & 0 & $1,40 \mathrm{E}-15$ & 0.70301 & 0.70229 & 0.99524 & 0 & 0.0000052 & 0.26843 & 0.98527 & 0.98526 & 0.70547 \\
\hline & $b$ & 0.070725 & 0.01352 & 0.01131 & 0.00362 & 0.63907 & 0.70354 & 0.00817 & 0.05331 & 0.01604 & 0.3900 & 0.56478 & 0.60455 & 0.42005 \\
\hline \multirow{2}{*}{5} & a & 0.05111 & 0 & 0.00028 & $2,54 \mathrm{E}-05$ & 0.70301 & 0.70257 & 0.99524 & 0 & $3,16 \mathrm{E}-06$ & 0.000088 & 0.98527 & 0.98526 & 0.70556 \\
\hline & b & 0.062463 & 0.00896 & 0.00555 & 0.00082 & 0.64803 & 0.70908 & 0.009 & 0.06543 & 0.01303 & 0.24276 & 0.6302 & 0.61757 & 0.66281 \\
\hline \multirow{2}{*}{6} & a & 0.048166 & 0 & 0.00028 & $1,68 \mathrm{E}-15$ & 0.70301 & 0.70257 & 0.99524 & 0 & 4,06E-04 & 0.00351 & 0.98527 & 0.98526 & 0.70907 \\
\hline & b & 0.06076 & 0.00041 & 0.01454 & 0.00895 & 0.64845 & 0.72362 & 0.01794 & 0.06956 & 0.01225 & 0.00041 & 0.69977 & 0.62983 & 0.66322 \\
\hline \multirow{2}{*}{7} & a & 0.04305 & 0.12572 & 0 & 2,77 E-14 & 0.82873 & 0.70257 & 0.99524 & 0 & 0.00016 & 0.06073 & 0.98527 & 0.98542 & 0.7698 \\
\hline & b & 0.058797 & 0.02728 & 0.00262 & 0.00294 & 0.67573 & 0.72624 & 0.02088 & 0.00253 & 0.0565 & 0.02259 & 0.7023 & 0.68632 & 0.68582 \\
\hline \multirow{2}{*}{8} & a & 0.041061 & $3,11 \mathrm{E}-13$ & 0.13382 & 2,38E-04 & 0.82873 & 0.83639 & 0.99524 & 0.00016 & 0 & 0.04166 & 0.98543 & 0.98542 & 0.81145 \\
\hline & $b$ & 0.048619 & 0.03671 & 0.01338 & 0.10938 & 0.71244 & 0.73962 & 0.13026 & 0.00199 & 0.00101 & 0.00016 & 0.70429 & 0.68733 & 0.68598 \\
\hline \multirow{2}{*}{9} & a & 0.032464 & $7,07 \mathrm{E}-16$ & 0.00033 & 0.00000908 & 0.82873 & 0.83672 & 0.99525 & 0 & 0 & 0.0001 & 0.98543 & 0.98542 & 0.81155 \\
\hline & b & 0.04622 & 0.00442 & 0.00606 & 0.13594 & 86 & 0.74568 & 0.2662 & 0.00851 & 0.00557 & 0.00101 & 0.71279 & 0.6929 & 0.68699 \\
\hline \multirow{2}{*}{10} & a & 0.031188 & 0.00319 & 0 & $1,28 \mathrm{E}-14$ & 0.83192 & 0.83672 & 0.99525 & 0.0010114 & 0.0000209 & 0 & 0.98543 & 0.98545 & 0.81165 \\
\hline & $b$ & 0.044453 & 0.06424 & 0.00593 & 0.03264 & 0.78111 & 0.75162 & 0.29884 & 0.00443 & 0.06203 & 0.00416 & 0.71722 & 0.75493 & 0.69115 \\
\hline \multirow[b]{2}{*}{11} & a & 0.030864 & $1,52 \mathrm{E}-12$ & 0.00002 & 0.00009875 & 0.83192 & 0.83674 & 0.99535 & 0.00001 & 0 & 0 & 0.98544 & 0.98546 & 0.81166 \\
\hline & $b$ & 0.020813 & 0.00215 & $\begin{array}{c}2.23 \mathrm{E}- \\
06\end{array}$ & 0.0001 & 0.89863 & 0.89002 & 0.71644 & 0.00069 & 0.00049 & 0.00664 & 0.808 & 0.80214 & 0.82883 \\
\hline \multirow{2}{*}{12} & a & 0.029827 & $8,89 \mathrm{E}-11$ & 0.0011 & 0.00000811 & 0.83192 & 0.83783 & 0.99536 & 0.00002 & 0.0000010 & 0.00034 & 0.98546 & 0.98546 & 0.812 \\
\hline & b & 0.020495 & 0.00067 & 0.00668 & $2.9 \mathrm{E}-07$ & 0.8993 & 0.89671 & 0.71644 & 0.00044 & 0.00041 & 0.0011 & 0.80844 & 0.80255 & 0.82993 \\
\hline \multirow{2}{*}{13} & a & 0.028786 & 0.02057 & 0 & 0 & 0.85249 & 0.83783 & 0.99536 & 0 & 0.0003 & 0.01215 & 0.98546 & 0.98575 & 0.82415 \\
\hline & b & 0.020304 & $4.5 \mathrm{E}-08$ & 0.00144 & $3.6 \mathrm{E}-06$ & 0.8993 & 0.89815 & 0.71644 & 0.00089 & 0.00011 & 0.00578 & 0.80932 & 0.80266 & 0.83571 \\
\hline \multirow{2}{*}{14} & a & 0.027023 & $2,14 \mathrm{E}-10$ & 0.01386 & 0.00000238 & 0.85249 & 0.85169 & 0.99536 & 0.00025 & $2,97 \mathrm{E}-04$ & 0.00431 & 0.98571 & 0.98575 & 0.82846 \\
\hline & b & 0.02016 & $8.8 \mathrm{E}-05$ & 0.00017 & 4.7E-06 & 0.89939 & 0.89832 & 0.71645 & 0.000010 & 0.00083 & 0.00639 & 0.80934 & 0.80349 & 0.84209 \\
\hline \multirow{2}{*}{15} & a & 0.026288 & $1,29 \mathrm{E}-09$ & 0.00291 & 0.00003203 & 0.85249 & 0.8546 & 0.9954 & 0.0001 & 0.00000399 & 0.00091 & 0.98581 & 0.98576 & 0.82937 \\
\hline & $b$ & 0.019373 & 0.00105 & 0.0019 & 0.00119 & 0.90043 & 0.90022 & 0.71763 & 0.0038 & 0.00143 & 0.00283 & 0.81313 & 0.80492 & 0.84492 \\
\hline \multirow[b]{2}{*}{16} & a & 0.024893 & 0.00123 & 0 & $8.8 \mathrm{E}-18$ & 0.85372 & 0.8546 & 0.9954 & 0 & 0.0000088 & 0.00124 & 0.98581 & 0.98577 & 0.83061 \\
\hline & $b$ & 0.019336 & 0.00013 & $\begin{array}{c}3.62 \mathrm{E}- \\
05\end{array}$ & 0.00285 & 0.90056 & 0.90025 & 0.72048 & 0.00031 & 0.00096 & 0.02442 & 0.81344 & 0.80588 & 0.86934 \\
\hline \multirow{2}{*}{17} & a & 0.024648 & $5.91 \mathrm{E}-16$ & 0.00009 & 0.00046 & 0.85372 & 0.85469 & 0.99586 & 0.00004 & 0.0000578 & 0.000029 & 0.98585 & 0.98582 & 0.83064 \\
\hline & $b$ & 0.01907 & $9.6 \mathrm{E}-05$ & 0.00027 & $4.5 \mathrm{E}-07$ & 0.90066 & 0.90052 & 0.72048 & 0.00216 & 0.00063 & 0.0001 & 0.8156 & 0.80651 & 0.86945 \\
\hline \multirow{2}{*}{18} & a & 0.024085 & 0.02787 & 0 & $2,51 \mathrm{E}-14$ & 0.88159 & 0.85469 & 0.99586 & 0 & 0.0000098 & 0.00818 & 0.98585 & 0.98583 & 0.83882 \\
\hline & $b$ & 0.019017 & 0.00027 & 0.00029 & 0.06465 & 0.90092 & 0.90081 & 0.78513 & $1,59 \mathrm{E}-04$ & 0.000042 & 0.00115 & 0.8156 & 0.80655 & 0.87059 \\
\hline
\end{tabular}

a: Sheikh Necmeddin; b: Erzen Hatun

Işı, E, Antep, B, Büyüksaraç, A.

https://doi.org/10.13167/2019.18.3 


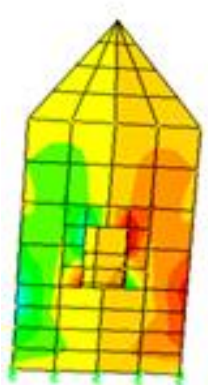

1. Mode $\mathrm{T} 1=0.7491$

\section{Sheikh Necmeddin}

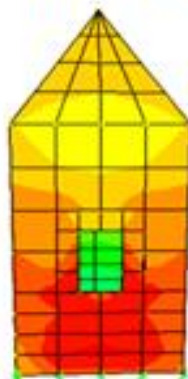

2. Mode

$\mathrm{T} 2=0.7935$

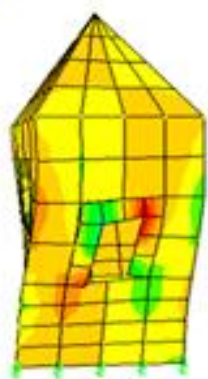

4. Mode

$\mathrm{T} 4=\mathbf{0} .0569$

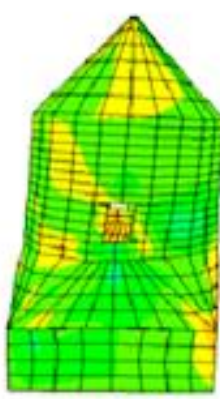

1. Mode

$\mathrm{T} 1=\mathbf{0 . 1 6 3 0}$

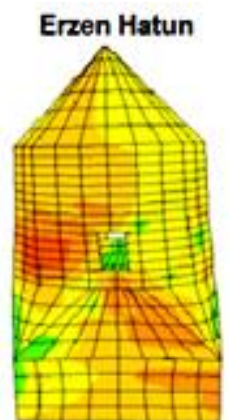

2. Mode

$\mathrm{T} 2=0.1413$

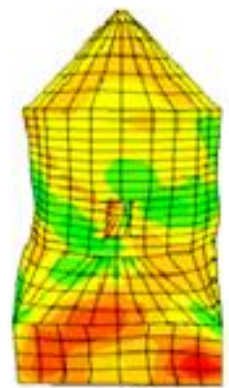

4. Mode

$\mathrm{T} 4=\mathbf{0 . 0 7 0 7}$

Figure 9 Modes and period values obtained for the tomb models

Static, dynamic, and earthquake loads were considered for tensile calculations. Static load calculation was performed by the software based on the material properties. The defined spectrum was utilized for the earthquake loads. For earthquake loads, two different directions of loads were defined as EQx and EQy. Using these values, calculations were made for different load combinations. The stress diagrams that were obtained based on the different loading conditions for S11, which were the vertical stress values in the $\mathrm{X}$ direction in the software, are shown in Figure 10.

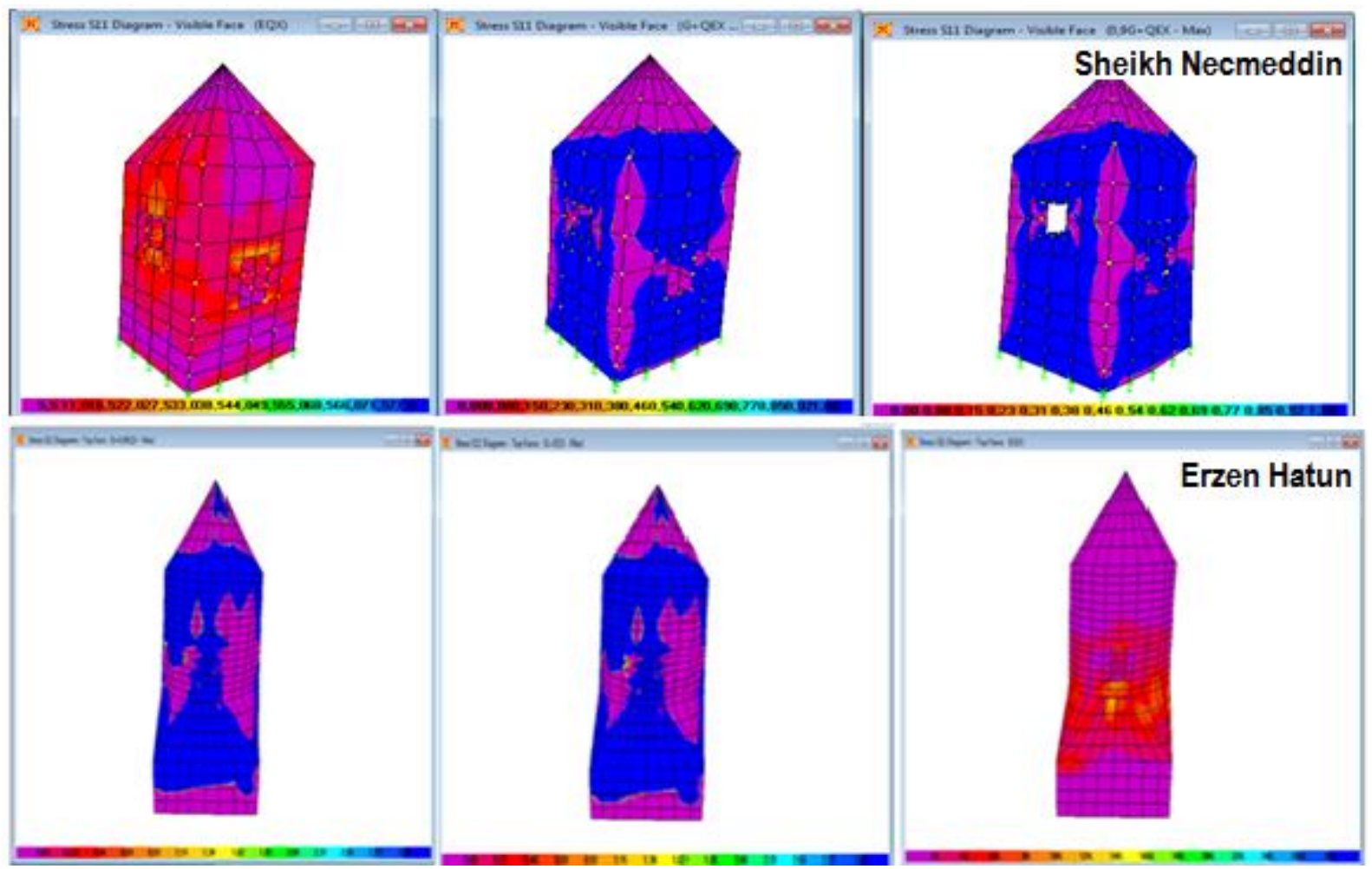

Figure 10 S11 stress values for different loading conditions

The stress diagrams obtained based on different loading conditions for S22, which were the vertical stress values in the $Y$ direction in the software, are shown in Figure 11. The stress diagrams obtained based on different loading conditions for $S 12$, which were the shear stress values in the $X-Y$ directions in the software, are shown in Figure 12.

Işık, E, Antep, B, Büyüksaraç, A. 


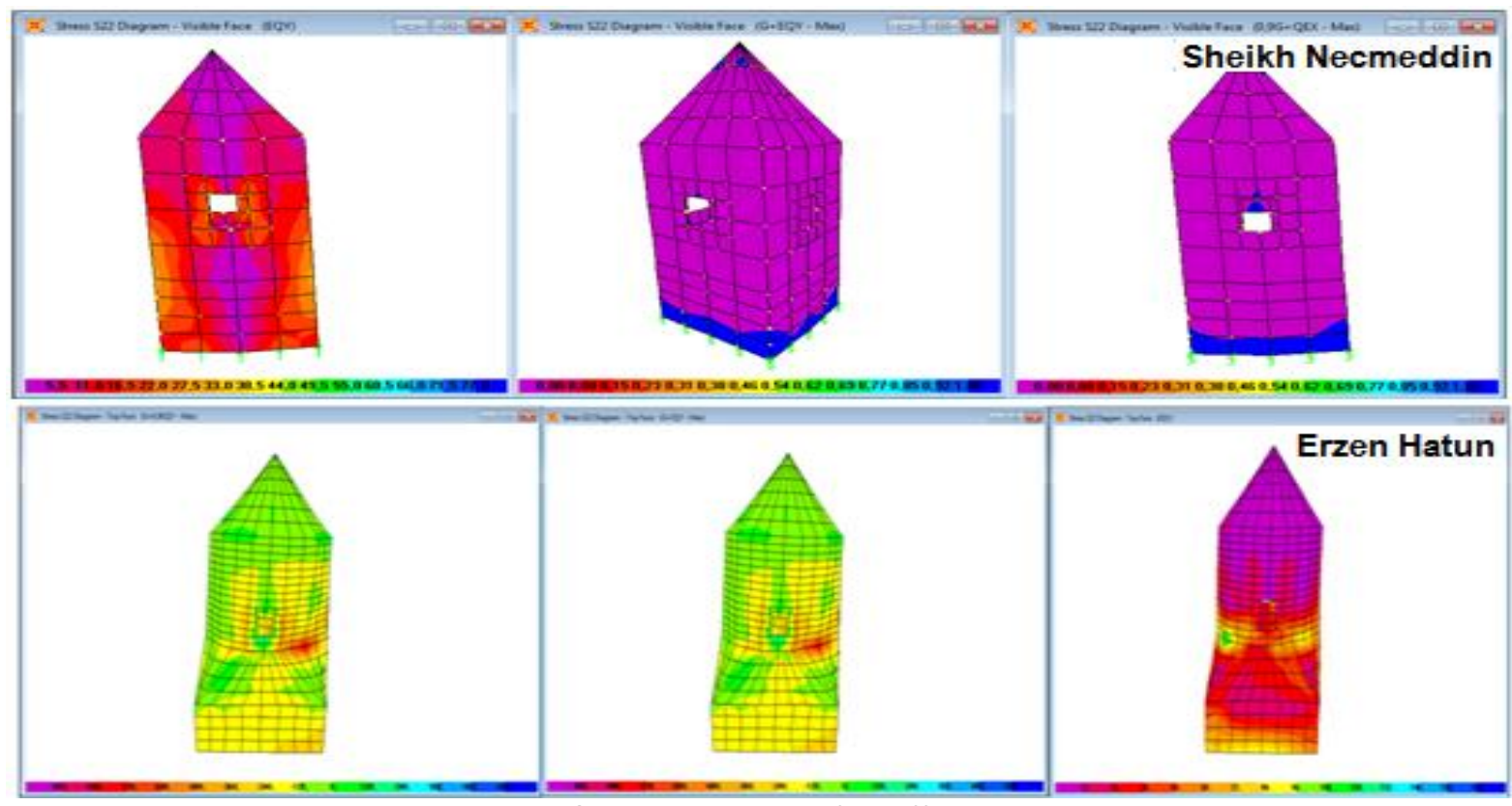

Figure $11 \mathrm{~S} 22$ stress values for different states

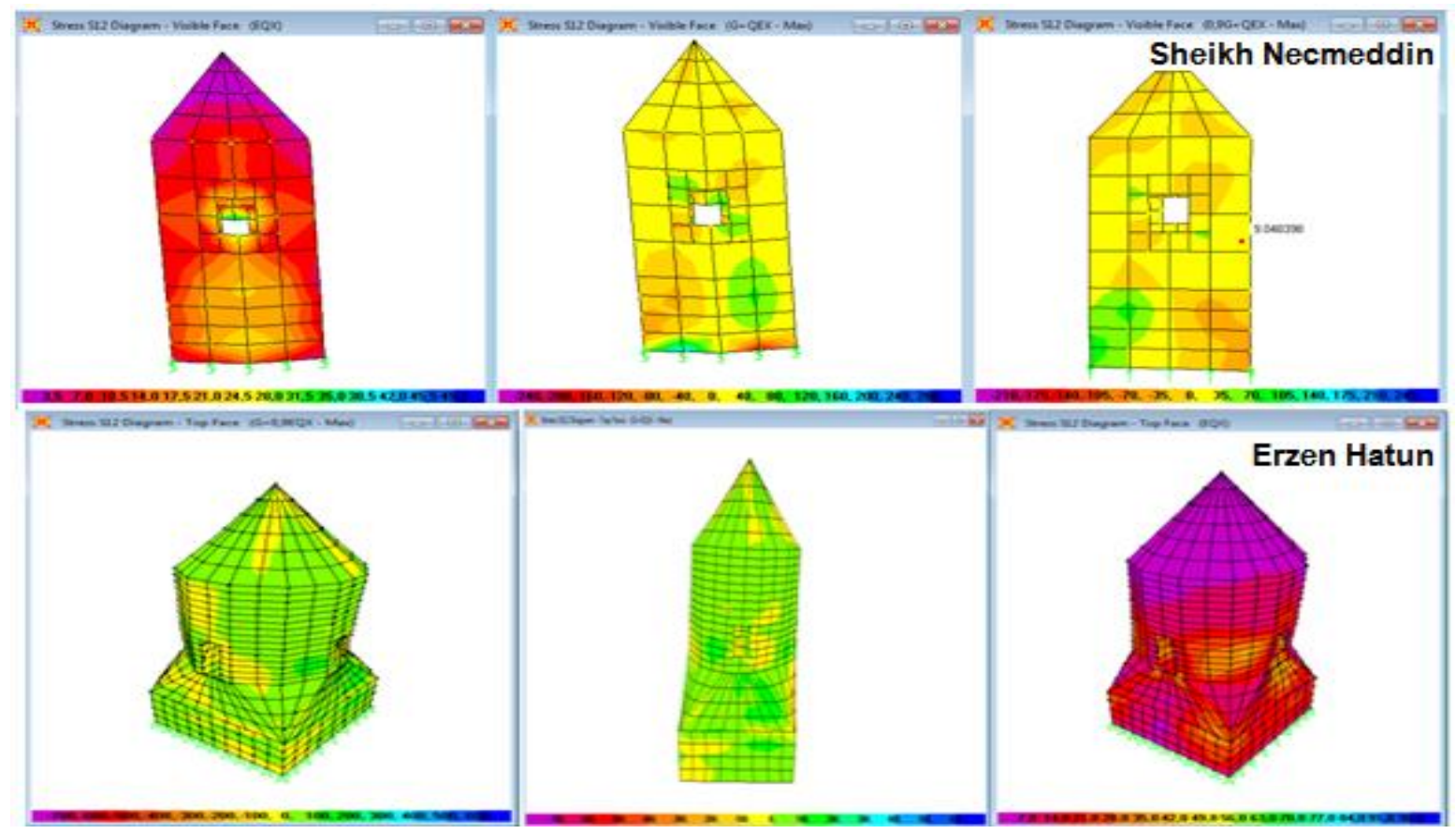

Figure 12 S12 stress values for different loading conditions

The maximum tensile stress values obtained from the analysis results are given in Table 5.

Table 5 Maximum tensile stresses under the earthquake effect

\begin{tabular}{ccccc}
\hline \multirow{2}{*}{ Load Type } & \multicolumn{2}{c}{ S11 (MPa) } & \multicolumn{2}{c}{ S22 (MPa) } \\
\cline { 2 - 5 } & Sheikh Necmeddin & Erzen Hatun & Sheikh Necmeddin & Erzen Hatun \\
\hline G+QEx & 0.860 & 0.6839 & 0.861 & 0.5498 \\
G+QEY & 0.861 & 0.6711 & 0.859 & 0.5246 \\
0.9G+ QEx & 0.773 & 0.203 & 0.775 & 0.5398 \\
G+ QEx +0,3 QEY & 0.860 & 0.706 & 0.861 & 0.572 \\
\hline
\end{tabular}

Işık, E, Antep, B, Büyüksaraç, A. 
The maximum compressive stress values obtained from the analysis results are given in Table 6 .

Table 6 Maximum compressive stresses under the earthquake effect

\begin{tabular}{ccccc}
\hline \multirow{2}{*}{ Load Type } & \multicolumn{2}{c}{ S11 (MPa) } & \multicolumn{2}{c}{ S22 (MPa) } \\
\cline { 2 - 5 } & Sheikh Necmeddin & Erzen Hatun & Sheikh Necmeddin & Erzen Hatun \\
\hline G+QEx & 0.395 & 0.957 & 1.092 & 1.343 \\
G+QEY & 0.398 & 1.105 & 1.104 & 1.352 \\
$0.9 G+Q E_{x}$ & 0.356 & 0.941 & 0.988 & 1.329 \\
G+ QEx $+0,3$ QEY & 0.397 & 1.019 & 1.093 & 1.388 \\
\hline
\end{tabular}

The maximum shear stress values obtained from the analysis results are given in Table 7.

Table 7 Maximum shear stresses under the earthquake effect

\begin{tabular}{ccc}
\hline \multirow{2}{*}{ Load Type } & \multicolumn{2}{c}{ S12 (MPa) } \\
\cline { 2 - 3 } & Sheikh Necmeddin & Erzen Hatun \\
\hline G+QEx & 0.255 & 0.870 \\
G+QEY & 0.255 & 0.895 \\
$0.9 G+Q E x$ & 0.230 & 0.862 \\
G+ QEx +0.3 QEY & 0.255 & 0.902 \\
\hline
\end{tabular}

\section{RESULTS}

This study examined some of the important structures of the Ahlat district, which has a rich historical texture. Structural analyses were performed for fifteen tombs. Initially the geometric positions of these tombs were obtained by in situ measurements. Based on the obtained values, a mapping process was carried out for the tombs being examined in the study. This study was the first of its kind in the town of Ahlat.

An observational analysis form was created for the damages that occurred in the tombs before the structural analysis. This form was filled separately for each tomb in the examinations. The emphasis was on the causes of damages and destructions that occurred in the tombs. In this study, the seismic behaviors of the two selected tombs were determined.

The Sheikh Necmettin and Erzen Hatun Tombs were chosen as examples for determination of the earthquake behaviors of the tombs in the Ahlat district. There have been studies on other tombs; however, these selections were made because these structures are different from the others. A finite element model was developed for the tomb constructed using solid elements in the masonry style. The stresses S11, S22, and S12 in the software were calculated for the finite element models. Additionally, the mode shapes and the period values of the tombs were obtained.

In time, mass losses, abrasions, and ruptures occurred in the stones under natural conditions. Additionally, lichen formations in these stones damaged them. Some stones had moisture effects due to water on the ground. The authorities continue to work on repairing these damages, and preventing and protecting the stones from further damage.

Despite the natural events and negative conditions experienced since the ancient times, the survival of these tombs allows creation of very accurate ideas in terms of the robustness of these structures. This shows that these historical buildings had good engineering services. Even in the historical process, it is an indication that the design of the structures was made in accordance with engineering knowledge.

Although the tombs were subjected to repairs over time, it was not possible to compare the damages and the analysis results. Timely interventions by the public organizations and the institutions concerned with the tombs helped in eliminating the risks. Because Ahlat stone has low strength and a spongy, soft structure, it is known to be prone to destruction by abrasion and gets affected by temperature differences, frost, humid environments, and these factors lead to destruction or separation of these stones. Freezing-thawing, cyclically effective in the cold season especially, is one of the most important factors in the destruction of the stones in the region and poses a risk for the tombs here.

Işık, E, Antep, B, Büyüksaraç, A. 


\section{Acknowledgments}

This work is derived from the postgraduate thesis by an author named Barış Antep.

\section{References}

[1] ICOMOS, 2002: International Cultural Tourism Charter. Principles and Guidelines for Managing Tourism at Places of Cultural and Heritage Significance. ICOMOS International Cultural Tourism Committee.

[2] Fetaher, J. 2006: Managing the documentary heritage: issues from the present and future. Preservation management for libraries, archives and museums. London: Facet. pp. 1-18.

[3] Işık, M.F.; Işık, E.; Bülbül, M.A.; Karaşin, I.B. 2017: QR Code application for geometric location and information of historical structures. International Conference on Advanced Engineering Technologies (ICADET 2017), Turkey.

[4] Işık, E.; Velioğlu, E.; Öztürk, G. 2016: Determination of seismic safety of a historic masonry building in Bitlis, BEU Journal of Science, 5(1), pp. 59-64, https://dx.doi.org/10.17798/beufen.10922 (in Turkish)

[5] Karaşin, I.B.; Işık, E. 2016.: Protection of Ten-Eyed Bridge in Diyarbakır, Budownictwol Architektura, 15(1), pp. 87-94.

[6] Ademović, N.; Kurtović, A.; Madžarević, M. 2017: Structural repair of Careva Ćuprija Bridge in Sarajevo. Građevinar, 68(12), pp.995-1008, https://doi.org/10.14256/JCE.1672.2016

[7] Hadzima-Nyarko, M.; Pavić, G.; Lešić, M. 2016: Seismic vulnerability of old confined masonry buildings in Osijek, Croatia. Earthquakes and Structures, 11(4), pp.629-648, https://doi.org/10.12989/eas.2016.11.4.629

[8] Hadzima-Nyarko, M.; Mišetić, V.; Morić. D. 2017: Seismic vulnerability assessment of an old historical masonry building in Osijek, Croatia, using Damage Index. Journal of Cultural Heritage, 28(2017), pp. 140150, https://doi.org/10.1016/j.culher.2017.05.012

[9] Ademović, N.; Kurtović, A. 2018: Stone and mortar in bridges from the Ottoman period in Bosnia and Herzegovina. Građevinar, 70 (03), pp. 213-224, https://doi.org/10.14256/JCE.2003.2017

[10] Backer, L.D., Janssens, A.; Steeman, M.; Paepe, M.D. 2018: Evaluation of display conditions of the Ghent altarpiece at St. Bavo Cathedral, Journal of Cultural Heritage, 29 (2018), pp.168-172, https://doi.org/10.1016/i.culher.2017.08.002

[11] Ortega, J.; Vasconcelos, G.; Rodrigues, H.; Correia, M.; Lourenço, P.B. 2017: Traditional earthquake resistant techniques for vernacular architecture and local seismic cultures: A literature review. Journal of Cultural Heritage, 27(2017), pp.181-196, https://doi.org/10.1016/..culher.2017.02.015

[12] Castellazzi, G.; D’Altri, A.M.; Miranda, S.; Ubertini, F. 2017: An innovative numerical modeling strategy for the structural analysis of historical monumental buildings. Engineering Structures, 132 (2017), pp.229-248, https://doi.org/10.1016/j.engstruct.2016.11.032

[13] Elyamani, A.; Roca, P.; Caselles, O.; Clapes, J. 2017: Seismic safety assessment of historical structures using updated numerical models: The case of Mallorca cathedral in Spain. Engineering Failure Analysis, 74(2017), pp. 54-79, https://doi.org/10.1016/i.engfailanal.2016.12.017

[14] Işık, E.; Antep, B. 2018: Structural analysis of historical masonry minaret in Ahlat. BEU Journal of Science7(1), pp. 46-56, https://dx.doi.org/10.17798/bitlisfen.416050 (in Turkish)

[15] Işık, E.; Antep, B.; Karaşin, I.B. 2018: Structural analysis of Ahlat Emir Bayındır Bridge. Bitlis Eren University Journal of Science \& Technology, 8(1), pp.11-18, https://dx.doi.org/10.17678/beuscitech.416908

[16] Hadzima-Nyarko, M.; Ademović, N.; Pavić, G.; Kalman Šipoš, T. 2018: Strengthening techniques for masonry structures of cultural heritage according to recent Croatian provisions. Earthquakes and Structures, 15(5), pp. 473-485, https://doi.org/10.12989/eas.2018.15.5.473

[17] Glavaš, H.; Hadzima-Nyarko, M.; Buljan, I.H.; Barić, T. 2019: Locating hidden elements in walls of cultural heritage buildings by using infrared thermography. Buildings, 9(2),32. https://doi.org/10.3390/buildings9020032

[18] Işık, E.; Aydın, M.C.; Ülker, M. 2016: Performance evaluation of a historical tomb and seismicity of the region, Bitlis Eren University, Journal of Science and Technology, 6(2), pp. 59-65, https://dx.doi.org/10.17678/beuscitech.297295

[19] Çavuş, M. 2013: Assessment of seismic behavior of historical Niksar Kulak Tomb under earthquake. Gaziosmanpaşa Journal of Scientific Research, 7, pp.80-90 (in Turkish)

Işık, E, Antep, B, Büyüksaraç, A. 
[20] Moin, K.; Arastu, M.; Khalil, M.; Amiri, A.S.; Qamar, S. 2019: Seismic stability analysis of historical construction: a case Study-Wazirpur Tomb. In Structural Analysis of Historical Constructions, 1419-1426. Springer, Cham. https://doi.org/10.1007/978-3-319-99441-3_152

[21] Tsokas, G.N.; Papazachos, C.B.; Vafidis, A.; Loukoyiannakis, M.Z.; Vargemezis, G.; Tzimeas, K., 1995: The detection of monumental tombs buried in tumuli by seismic refraction. Geophysics, 60(6), pp.1735-1742. https://doi.org/10.1190/1.1443906

[22] Vafidis, A.; Tsokas, G.N.; Loucoyannakis, M.Z.; Vasiliadis, K.; Papazachos, C.B.; Vargemezis, G. 1995: Feasibility study on the use of seismic methods in detecting monumental tombs buried in tumuli. Archaeological Prospection, 2(3), pp.119-128, https://doi.org/10.1002/1099-0763(199509)2:3\%3c119::AIDARP6140020302\%3e3.0.CO;2-1

[23] Işık, E.; Antep, B.; Büyüksaraç, A.; Aydın, M.C. 2018: Erzen Hatun Kümbetinin yapısal analizi. UMTEB - 4. Uluslararası Mesleki ve Teknik Bilimler Kongresi, Erzurum, Turkey (in Turkish)

[24] Baykal. O.; Tarı, E.; Coşkun, Z. 2009: Mühendislik Ölçmeleri-I Kara ve Demiryollarında Geçki Geometrisi Tasarımı ve Aplikasyonu, Cilt-I Sayısal Örnekler. Birsen Yayınevi, İstanbul, Turkey (in Turkish)

[25] Songu, C.; Şerbetçi. M.; Gülal, E. 2009: Ölçme Bilgisi. Birsen Yayınevi, İstanbul, Turkey (in Turkish)

[26] Computer and Structures Inc. 2004: SAP 2000 V14.0.0 (Software), Berkeley, CA.

[27] Turkish Earthquake Code (TEC), 2007: Turkish earthquake code-specification for structures to be built in disaster areas, Turkey (in Turkish)

[28] Mutlu, Ö.; Şahin, A. 2016: Investigating the effect of modeling approaches on earthquake behavior of historical masonry minarets-Bursa Grand Mosque case study. Sigma Journal of Engineering and Natural Sciences, 7(2), pp.123-136 (in Turkish)

[29] Dabanlı, Ö. 2008: Determination of the earthquake performance of historical masonry structures. Master Thesis, İstanbul Technical University, Istanbul, Turkey (in Turkish)

Please cite this article as:

Işık, E.; Antep, B.; Büyüksaraç, A.: Structural analysis and mapping of historical tombs in Ahlat district (Bitlis, Turkey), Electronic Journal of the Faculty of Civil Engineering Osijek-e-GFOS, 2019, 18, pp. 22-35, https://doi.org/10.13167/2019.18.3 